\title{
Enumeration and molecular detection of Bacillus cereus in local indigenous and imported rice grains
}

\author{
Lesley Maurice Bilung ${ }^{1 * \dagger}$, Ahmad Syatir Tahar ${ }^{1 \dagger}$, Tan Pei Shze ${ }^{1 \dagger}$, Samantha Valarie Furzanne Anak Jamie ${ }^{1 \dagger}$, \\ Hashimatul Fatma Hashim ${ }^{1 \dagger}$, Kasing Apun ${ }^{1 \dagger}$ and Son Radu ${ }^{2+}$
}

\begin{abstract}
Background: Bacillus cereus is frequently related to foodborne illness outbreak. The common food vehicles for transmission of the bacteria are rice, rice products and starchy foods. As rice is a staple food for some countries including Malaysia, knowledge about safety of $B$. cereus in rice is important. This study was conducted to enumerate and identify B. cereus in local indigenous and imported rice grains. As Malaysia depends on imported rice to complement the food demands, it is crucial to assess on the imported rice besides the locals.

Results: Twenty local indigenous and twenty imported rice grains were investigated in this study. All samples showed positive for the presence of $B$. cereus using polymerase chain reaction targeting the gryB gene (475 bp) which encodes for B protein subunit for DNA gyrase or also known as topoisomerase II. The microbial load of B. cereus in all samples was $>1100 \mathrm{MPN} / \mathrm{g}$. However, PCR analysis revealed all the samples were contaminated with $B$. cereus except for three samples of local indigenous rice (LIR 3, LIR 9 and LIR 20).
\end{abstract}

Conclusions: Due to the finding of high prevalence on the samples, it is therefore concluded that the local indigenous and imported rice grains can be one potential source of $B$. cereus transmission to the public.

Keywords: Bacillus cereus, Enumeration, gryB gene, Polymerase chain reaction, Rice

\section{Background}

Food poisoning caused by Bacillus cereus is frequently associated with consumption of contaminated fried rice. The foodborne bacteria produce endospore which is resistant towards heat. They are able to grow in the temperature of $10-48{ }^{\circ} \mathrm{C}$, and temperatures ranging from 28 to $35^{\circ} \mathrm{C}$ are the optimum. To date, the available treatments for the disinfection are used which are high temperature for canning and lowering $\mathrm{pH}$ [6]. B. cereus pathogenesis depends on amount of dose consumed and site of the bacteria producing toxin in either food or

\footnotetext{
*Correspondence: mblesley@unimas.my

†Lesley Maurice Bilung, Ahmad Syatir Tahar, Tan Pei Shze, Samantha Valarie Furzanne Anak Jamie, Hashimatul Fatma Hashim, Kasing Apun and

Son Radu contributed equally to this work

${ }^{1}$ Department of Molecular Biology, Faculty of Resource Science

and Technology, Universiti Malaysia Sarawak, 94300 Kota Samarahan,

Sarawak, Malaysia

Full list of author information is available at the end of the article
}

intestine [16]. The bacterial infection is manifested with diarrhoea and emesis.

Local rice in Sarawak contributes 214.97 tonne valued at RM 369,551 representing $3.7 \%$ of the total export value of agricultural product [8]. Rice cultivation in Sarawak had always been on a subsistence cash crop basis with low yields because of tough hilly terrains, drought, poor drainage and irrigation and lack of modern machinery usage. Rice is cultivated manually using traditional methods, and in some places, machinery is used to increase the yield. In spite of these setbacks, the local farmers had produced some of the world finest and very best homegrown aromatic rice. Notable traditional rice produced in Sarawak are the Bario rice, Biris rice, Bajong rice, Beras Hitam or black rice and Beras Merah or red rice. There are other aromatic rice varieties, namely Kanowit rice, Wangi rice, Rotan rice, Bali rice, Mamut rice, Selasih rice, Kateh Merah, Lemak rice and the black glutinous 
rice. As the society became more affluent and health conscious, focus now has shifted to the local pesticide-free produce and high nutritional value [15]. In tandem with food security and fulfilment of the requirement of rice by Malaysians, imported rice is also retailed in markets. The most demanded imported rice in Malaysia are Thai White Rice and Vietnamese White Rice [4].

The $\operatorname{gyr} B$ gene encodes subunit B protein of DNA gyrase (topoisomerase type II), which is essential for DNA replication [3]. The gene is used in phylogenetic and taxonomic analysis since it is ubiquitous even in different bacterial species. Furthermore, the gene has better efficiency than its counterpart, 16S rRNA because of faster evolutionary rate which contributes to lesser percentage of gene similarities, even among closely related species [19] and therefore suitable for bacterial species identification. A study conducted by Bavykin et al. [3] showed that the percentage of gene similarity of $16 \mathrm{~S}$ rRNA in closely related species can be up to $100 \%$, which makes it hard to distinguish between the species. By comparison, Wang et al. [19] stated that the percentages of gene similarity of $\operatorname{gyrB}$ between the species are up to $99.2 \%$. Up to the present time, Malaysia has not had any official statistics on $B$. cereus outbreak, but there are a few reports regarding incidences of $B$. cereus in food such as ready-to-eat cereals [5], raw and cooked chicken meats [1] and readyto-eat cooked rice [17] and cooked rice [12]. There has been no study of B. cereus in imported rice in Malaysia. This shows screening of $B$. cereus from food is crucial and positive findings may help further initial preventative measures of outbreak from occurring.

\section{Methods}

\section{Sample collection and enumeration}

Twenty local indigenous rice grains (Bario bukit, Bario paya, Limbang, Pulut chelum, Bubuk, Buran, Empenit, Ginti bukit, Ginti paya, Katun, Kicap, Mamut, Melanjan, Melawi, Padi mit, Samak, Saratok, Sebuti, Selasih and Tarat) were collected in Sarawak, and twenty imported rice grains were purchased at retail shops and hypermarkets in Malaysia. The samples were transported to the laboratory for further analysis. Twenty grams for each sample was added into stomacher bag containing $180 \mathrm{ml}$ of tryptic soy broth (Difco, US). The bag was shaken for $60 \mathrm{~s}$ and further incubated at $37^{\circ} \mathrm{C}$ for $20 \mathrm{~h}$ [17]. Enumeration was conducted by using most probable number (MPN) three-tube serial dilution. Tubes were incubated at $37^{\circ} \mathrm{C}$ for $24 \mathrm{~h}$.

\section{DNA extraction and polymerase chain reaction}

The bacterial DNAs were extracted by using the boil cell method as described by Lee et al. [13]. One millilitre of the culture was centrifuged at $12,000 \times g$ for $1 \mathrm{~min}$.
Subsequent re-suspension was done in $500 \mu \mathrm{l}$ of distilled water. The mixture was boiled for $20 \mathrm{~min}$ and followed by prompt cooling at $-20{ }^{\circ} \mathrm{C}$ for $10 \mathrm{~min}$. Then, the mixture was centrifuged again at $12,000 \times g$ for $5 \mathrm{~min}$ and only the supernatant was retained for PCR method.

Molecular techniques were performed to identify $B$. cereus from the concentrated DNA by following the method by $\mathrm{Wu}$ et al. [18]. The gyrB gene was amplified using BCJH-F primer (5'-TCATGAAGAGCCTGTGTACG-3') and BCJH-1R primer (5'-CGACGTGTCAATTCACGCGC-3') which produced 475-bp amplicons [17]. The PCR consisted of $3.0 \mu \mathrm{L}$ of DNA template, $5.0 \mu \mathrm{L}$ of $5 \mathrm{X}$ PCR buffer, $2.0 \mu \mathrm{L}$ of $1.0 \mu \mathrm{M}$ BCJH-1R primer, $2.0 \mu \mathrm{L}$ of $1.0 \mu \mathrm{M}$ BCJH-F primer, $0.8 \mu \mathrm{L}$ of $1.0 \mathrm{U} \mathrm{Taq}$ polymerase, $0.4 \mu \mathrm{L}$ of $0.2 \mathrm{mM}$ deoxynucleoside triphosphate (dNTP) mix, $0.6 \mu \mathrm{L}$ of $1.5 \mathrm{mM}$ $\mathrm{MgCl}_{2}$ and $6.2 \mu \mathrm{L}$ of double-distilled water to make up to $20 \mu \mathrm{L}$ of the PCR mixture. The PCR was conducted with an initial denaturation at $94{ }^{\circ} \mathrm{C}$ for $3 \mathrm{~min}$, followed by denaturation at $94{ }^{\circ} \mathrm{C}$ for $45 \mathrm{~s}$, annealing at $63{ }^{\circ} \mathrm{C}$ for $1 \mathrm{~min}$, elongation at $72{ }^{\circ} \mathrm{C}$ for $1 \mathrm{~min}$ and final extension at $72{ }^{\circ} \mathrm{C}$ for $7 \mathrm{~min}$. The amplicons were analysed via $1.0 \%$ of agarose gel electrophoresis in $1 \times$ TBE buffer (BioRad, Spain) at $90 \mathrm{~V}$ for $60 \mathrm{~min}$. A 100-bp DNA ladder (Thermo Scientific Fermentas), B. cereus positive control and DNAse/RNAse-free water as negative control were included. The gel was stained with $1 \mu \mathrm{g} / \mathrm{ml}$ ethidium bromide for $15 \mathrm{~min}$ and visualised under UV light.

\section{Results}

Enumeration of $B$. cereus via most probable number analysis showed $100 \%(20 / 20)$ samples of local indigenous and $100 \%(20 / 20)$ of imported rice grains had high occurrence of the bacteria which had more than 1100 MPN/g per sample. Subsequent PCR detection found $85 \%(17 / 20)$ of the local indigenous rice grains and $100 \%$ (20/20) of the imported rice grains were detected positive with $B$. cereus. The prevalence is presented in Table 1 . Representative amplifications of the gyr $\mathrm{B}$ gene for the detection of B. cereus ( $475 \mathrm{bp}$ ) in the samples are displayed in Figs. 1 and 2.

\section{Discussion}

In this study, MPN analysis of the forty samples for local indigenous $(n=20)$ and imported $(n=20)$ rice grains turned turbid after the incubation and the bacterial concentration was $>1100 \mathrm{MPN} / \mathrm{g}$ for each rice grain sample. Based on the permitted level of B. cereus in food by the Food Standards Australia New Zealand [9], the bacterial allowable level is below $10^{2} \mathrm{CFU} / \mathrm{g}$. However, the amount of $\geq 10^{4} \mathrm{CFU} / \mathrm{g}$ is considered unsafe and may result in immediate recall of the foodstuffs for further inspection if in retails. However, the indicator level in the 
Table 1 Results for most probable number and PCR analysis of B. cereus in local indigenous and imported rice grains

\begin{tabular}{|c|c|c|c|c|c|c|c|}
\hline Types of sample & Sample codes & $\mathrm{MPN} / \mathrm{g}$ & PCR analysis & Types of sample & Sample codes & $\mathrm{MPN} / \mathrm{g}$ & PCR analysis \\
\hline \multirow[t]{20}{*}{ Local indigenous rice grains } & LIR 1 & $>1100$ & $+^{a}$ & Imported rice grains & IR 1 & $>1100$ & $+^{\mathrm{a}}$ \\
\hline & LIR 2 & $>1100$ & + & & IR 2 & $>1100$ & + \\
\hline & LIR 3 & $>1100$ & - & & IR 3 & $>1100$ & + \\
\hline & LIR 4 & $>1100$ & + & & IR 4 & $>1100$ & + \\
\hline & LIR 5 & $>1100$ & + & & IR 5 & $>1100$ & + \\
\hline & LIR 6 & $>1100$ & + & & IR 6 & $>1100$ & + \\
\hline & LIR 7 & $>1100$ & + & & IR 7 & $>1100$ & + \\
\hline & LIR 8 & $>1100$ & + & & IR 8 & $>1100$ & + \\
\hline & LIR 9 & $>1100$ & - & & IR 9 & $>1100$ & + \\
\hline & LIR 10 & $>1100$ & + & & IR 10 & $>1100$ & + \\
\hline & LIR 11 & $>1100$ & + & & IR 11 & $>1100$ & + \\
\hline & LIR 12 & $>1100$ & + & & IR 12 & $>1100$ & + \\
\hline & LIR 13 & $>1100$ & + & & IR 13 & $>1100$ & + \\
\hline & LIR 14 & $>1100$ & + & & IR 14 & $>1100$ & + \\
\hline & LIR 15 & $>1100$ & + & & IR 15 & $>1100$ & + \\
\hline & LIR 16 & $>1100$ & + & & IR 16 & $>1100$ & + \\
\hline & LIR 17 & $>1100$ & + & & IR 1 & $>1100$ & + \\
\hline & LIR 18 & $>1100$ & + & & IR 2 & $>1100$ & + \\
\hline & LIR 19 & $>1100$ & + & & IR 3 & $>1100$ & + \\
\hline & LIR 20 & $>1100$ & - & & IR 4 & $>1100$ & + \\
\hline
\end{tabular}

a Symbols ( \pm ) indicate positive and negative result of the presence of $B$. cereus

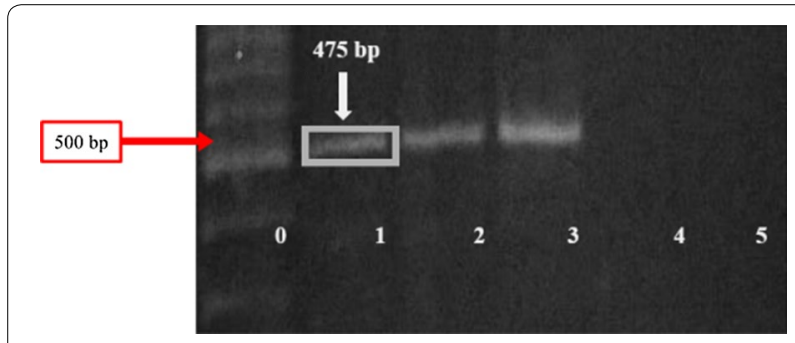

Fig. 1 Representative amplifications of the gyrB gene for the detection of B. cereus (475 bp) in the samples. Sample: ILR 18. Lane 0 100-bp molecular ladder (Thermo Scientific Fermentas), Lane 1 B. cereus positive control, Lanes 2 and 3 B. cereus positive samples (replicates 1 and 2), Lane 4 negative sample (replicate 3), Lane 5 negative control

UK is different where it is regarded as hazardous if only $>10^{5} \mathrm{CFU} / \mathrm{g}$. Meanwhile, the UK's allowable limit is below $10^{3} \mathrm{CFU} / \mathrm{g}$ [16]. With regard to the finding obtained in this study, the rice grain samples were concluded as risky for consumption and unsatisfactory. This is in agreement with the previous research by Sandra et al. [17] where $B$. cereus was found $>1100 \mathrm{MPN} / \mathrm{g}$ in all cooked rice grain samples.

The PCR analysis revealed that $85 \%(17 / 20)$ of the local indigenous and $100 \%(20 / 20)$ of imported rice grains were positive with $B$. cereus. Only three local rice grains were negative towards $B$. cereus, and therefore, this study suggests the three samples were contaminated with other

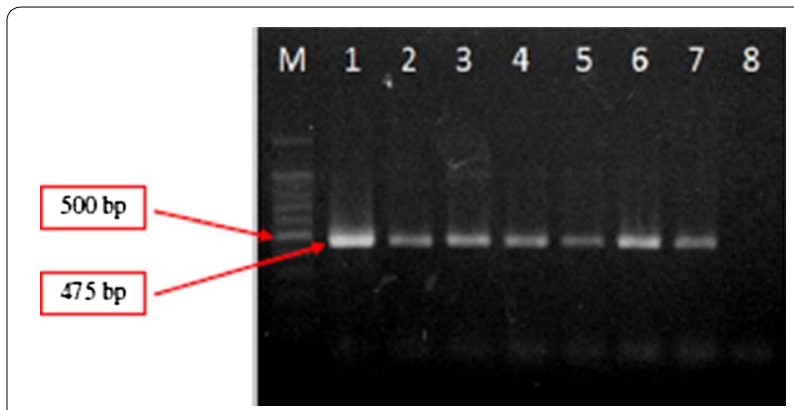

Fig. 2 Representative amplifications of the gyrB gene for the detection of B. cereus (475 bp) in the samples. Sample: IR 17. Lane M 100-bp molecular ladder (Thermo Scientific Fermentas), Lane 1 B. cereus positive control, Lanes 2-7 samples, Lane 8 negative control

endophytic bacteria due to positive result of contamination from MPN analysis. Endophytic bacteria are found from surface-sterilised or inside plants and have no harmful effect to plant [14]. Nonetheless, local rice grains might have undergone stringent quality control through Food Regulations 1985 and Food Act 1983. The high bacterial prevalence in the food samples is comparable to the finding obtained by Sandra et al. [17] where 100\% (25/25) of raw local rice grains were $B$. cereus positive. However, there was lower level of contamination where $46.6 \%$ $(83 / 178)$ of the isolated US rice were detected with $B$. cereus [2]. In addition to that, $18.5 \%(10 / 54)$ of rice dishes 
samples were identified in Belgium having positive with the bacterial contamination [7]. However, both protocols applied by Ankolekar et al. [2] and Delbrassinme et al. [7] involved selective plating on agar instead of molecular detection.

The bacteria can cause disease if ingested in high amount by producing toxin in either food or intestine. The minimum cell dose for B. cereus pathogenicity is in the range of $10^{5}-10^{8}$ of cells or spores per gram. Ingestion greater cell or spore concentration than as stated leads to risk for diarrhoeal $\left(10^{5}-10^{7}\right.$ cells/g) and emetic $\left(10^{5}-10^{7}\right.$ cells $\left./ g\right)$ syndromes. These syndromes differ with the types of symptom manifested. Diarrhoeal syndrome causes diarrhoea, abdominal cramp and nausea; however, emetic syndrome causes vomiting, nausea, malaise and emesis [10]. In this study, the occurrence of the bacterial concentration was higher than $1100 \mathrm{MPN} / \mathrm{g}$ for each sample which points out that all the local indigenous and imported rice grains might not be safe for consumption. Therefore, local authorities have to enforce and regulate laws regarding the safety of commercial rice grains for trade in Malaysia. Besides, commercial food companies have to comply with the regulations to ensure the products are safe to consumers.

The presence of $B$. cereus from raw rice grains can be caused by contamination during growth, harvesting and subsequent processes. The bacteria have potential to cause food poisoning as rice grain is normally stored at $12-14 \%$ of moisture content, and this permits the bacterial proliferation [11]. Besides, improper washing prior boiling leaves the residual spores on the rice grains [17]. B. cereus endospores are resistant and have higher survivability, especially when the food is left at room temperature. Therefore, they have potential to germinate and re-grow to a pathogenic form of $B$. cereus.

\section{Conclusion}

This integrated study involving both Malaysian and imported rice grains is important to reveal the presence of $B$. cereus in food. This is the first preliminary report on the occurrence of $B$. cereus in imported rice grains in Malaysia. This study provides explanations of risks of the public contracting the illness as the studied rice is staple food for Malaysians. As precautionary measures should be taken, cooked rice grains should be promptly consumed, otherwise kept at below $7^{\circ} \mathrm{C}$ or higher than $63^{\circ} \mathrm{C}$ within $2 \mathrm{~h}$ of cooking to avoid germination of the spores. Prompt cooling or heating the food for storage can minimise the potential of the spore to germinate during the holding time. As improvement for further research, it should be performed on toxigenic spores of Bacillus species in Malaysia which might give insight into the bacterial pathogenesis.

\section{Abbreviations}

CFU: colony-forming units; MPN: most probable number; LIR: local indigenous rice; IR: indigenous rice; PCR: polymerase chain reaction.

\section{Authors' contributions}

$L M B$ conceived the study, was involved in the design and coordination of study and manuscript drafting. AST was involved in the manuscript drafting and editing. TPS and SVFJ were involved in the sampling collection, processing and data analysis. HFT, KA and SR were involved in the final editing of the manuscript. All authors read and approved the final manuscript.

\section{Author details}

${ }^{1}$ Department of Molecular Biology, Faculty of Resource Science and Technology, Universiti Malaysia Sarawak, 94300 Kota Samarahan, Sarawak, Malaysia.

2 Department of Food Science, Faculty of Food Science and Technology,

Universiti Putra Malaysia (UPM Serdang), 43400 Serdang, Selangor, Malaysia.

\section{Acknowledgements}

This project was partially funded by Ministry of Higher Education Malaysia under (Research Acculturation Collaboration Effort) RACE Grant Scheme, RACE/b(3)/1095/2013(3)

\section{Competing interests}

The authors declare that they have no competing interests.

\section{Availability of supporting data}

The data generated and analysed in this study are available to readers as in the manuscript.

Received: 19 August 2016 Accepted: 2 November 2016

Published online: 03 December 2016

\section{References}

1. Aklilu E, Tukimin EB, Daud NBA, Kyaw T. Enterotoxigenic Bacillus cereus from cooked chicken meat: a potential public health hazard. Malays J Microbiol. 2016;12:112-5.

2. Ankolekar C, Rahmati T, Labbé RG. Detection of toxigenic Bacillus cereus and Bacillus thuringiensis spores in US rice. Int J Food Microbiol. 2009:128:460-6.

3. Bavykin SG, Lysov YP, Zakhariev V, Kelly JJ, Jackman J, Stahl DA, Cherni A. Use of $16 \mathrm{~S}$ rRNA, 23S rRNA, and gyrB gene sequence analysis to determine phylogenetic relationships of Bacillus cereus group microorganisms. J Clin Microbiol. 2004;42:3711-30.

4. BERNAS. Imported white rice. 2016. www.bernas.com.my/index.php/ imported-white-rice.

5. Bilung LM, Linang V, Noaman YA, Apun K, Lihan S. Presence of Bacillus cereus s.l. from ready-to-eat cereals (RTE) products in Sarawak. Int Food Res J. 2013;20:1031-4.

6. Budka H, Buncic S, Colin P. Opinion of the scientific panel on biological hazards on Bacillus cereus and other Bacillus spp. in foodstuffs. Eur Food Saf Auth J. 2005;175:1-48.

7. Delbrassinne L, Andjelkovic M, Dierick K, Denayer S, Mahillon J, Van Loco J. Prevalence and levels of Bacillus cereus emetic toxin in rice dishes randomly collected from restaurants and comparison with the levels measured in a recent foodborne outbreak. Foodborne Pathog Dis. 2012;9:809-14

8. Department of Agricultural Sarawak. 2012. www.doa.sarawak.gov.my/ modules/web/pages.php?mod=webpage\&sub=page\&id=690.

9. Food Standards Australia New Zealand. Guidelines for microbiological examination of ready-to-eat foods. 2001. www.foodstandards.gov.au/ publications/Pages/guidelinesformicrobi1306.aspx.

10. Granum PE. Bacillus cereus. In: Pina LMF, Arun KB, James S, editors. Foodborne pathogens: microbiology and molecular biology. Norfolk: Caister Academic Press; 2005. p. 409-14.

11. Haque A, Russell NJ. Phenotypic and genotypic characterisation of Bacillus cereus isolates from Bangladeshi rice. Int J Food Microbiol. 2005;98:23-34. 
12. Jawad N, Mutalib SA. Identification of Bacillus cereus isolates from cooked rice by biochemical test and $16 \mathrm{~s} \mathrm{rDNA}$ sequences. Int J ChemTech Res. 2016;9:469-75.

13. Lee HY, Chai LC, Tang SY, Jinap S, Ghazali FM, Nakaguchi Y, Nishibuchi M, Son R. Application of MPN-PCR in biosafety of Bacillus cereus s.l. for readyto-eat cereals. Food Control. 2009;20:1068-71.

14. Mano H, Morisaki H. Endophytic bacteria in the rice plant. Microbes Environ. 2008;23:109-17.

15. New Straits Times. 2012. www.nst.com.my.

16. Public Health England. Guidelines for assessing the microbiological safety of ready-to-eat foods placed on the market. 2009. www.gov.uk/government/publications/ ready-to-eat-foods-microbiological-safety-assessment-guidelines.
17. Sandra A, Afsah-Hejri L, Tunung R, Tuan Zinazor TC, Tang JYH, Ghazali FM, Nakaguchi Y, Nishibuchi M, Son R. Bacillus cereus and Bacillus thuringiensis in ready-to-eat cooked rice in Malaysia. Int Food Res J. 2012;19:829-36.

18. Wu XY, Walker MJ, Hornitzky M, Chin J. Development of a group-specific PCR combined with ARDRA for the identification of Bacillus species of environmental significance. J Microbiol Methods. 2006;64:107-19.

19. Wang $L T$, Lee $F L$, Tai CJ, Kasai H. Comparison of gyrB gene sequences, $16 \mathrm{~S}$ rRNA gene sequences and DNA-DNA hybridization in the Bacillus subtilis group. Int J Syst Evolut Microbiol. 2007;57:1846-50.

\section{Submit your next manuscript to BioMed Central and we will help you at every step:}

- We accept pre-submission inquiries

- Our selector tool helps you to find the most relevant journal

- We provide round the clock customer support

- Convenient online submission

- Thorough peer review

- Inclusion in PubMed and all major indexing services

- Maximum visibility for your research

Submit your manuscript at www.biomedcentral.com/submit 